\title{
How high-resolution DEM based on airborne LiDAR helped to reinterpret landforms - examples from the Sudetes, SW Poland
}

\author{
Piotr Migoń, Marek Kasprzak, Andrzej Traczyk \\ Institute of Geography and Regional Development, University of Wrocław, Poland, piotr.migon@uni.wroc.pl
}

\begin{abstract}
The paper reviews recent advances in landform mapping and interpretation in the mountainous terrain of the Sudetes (SW Poland), possible due to the availability of high-resolution airborne LiDAR data. They are particularly useful in the recognition of minor landforms and their spatial patterns in the montane forest belt and in the dwarf pine zone in the most elevated parts of the Sudetes. The use of LiDAR data has allowed to both re-evaluate landforms known before, especially their extent and cross-relationships, as well as to discover surface features that have escaped attention before. The examples discussed include glacial and periglacial landforms in the Karkonosze, morphological signatures of mass movements in the Stołowe Mountains, fluvial features and morphotectonic analysis in the Izerskie Mountains. Although LiDAR immensely increases the scope for landform recognition and mapping, image interpretation should be verified in the field. Despite theoretical capability of LiDAR-derived models to show even landforms 1-2 $\mathrm{m}$ in length, 4-6 $\mathrm{m}$ seems the more realistic threshold size unless surface features are distinctly linear and continue over long distances.
\end{abstract}

Key words: LiDAR, DEM, geomorphometry, geomorphological mapping, Sudetes

\section{Introduction}

In recent years we observe rapid developments in acquisition techniques of high-quality data on Earth surface topography (Wilson, Bishop 2013). Among these new sources of data is airborne laser scanning (ALS Wasklewicz et al. 2013), also known as LiDAR (Light Detection and Ranging), which provides high resolution information about the configuration of land surface and hence, is used to build detailed digital elevation models. LiDAR data are used for many purposes in geomorphology, but are particularly useful in geomorphological mapping (Höfle, Rutzinger 2011, Bishop 2013, Napieralski et al. 2013). The advantages of LiDAR include its ability to penetrate through forest canopies and to detect minor topographic features, which proves invaluable in mapping densely forested terrain, even if the ground is accessible physically and can be walked on. Recent examples of successful utilization of LiDAR data for mapping landforms include the recognition of subtle geomorphic signatures of landslides (Van Den Eeckhaut et al. 2007), tectonic features (Kondo et al. 2008, Lin et al. 2013), and fluvial landforms on floodplains (Notebaert et al. 2009).

In Poland the use of airborne LiDAR data for geomorphological purposes, especially landform mapping, has so far been very limited. They helped in landslide mapping in the Carpathians (Borkowski et al. 2011, Wojciechowski et al. 2012) and enriched our understanding of landform inventory and evolution in the vicinity of Mt Kasprowy Wierch, Tatra Mts (Wójcik et al. 2013). In the Sudetes, SW Poland, LiDAR-derived DEMs were first used to update geological maps for the Karkonosze Mts (Knapik et al. 2009) and the Stołowe Mountains (Wojewoda et al. 2011), and somehow parallel, in geomorphology, to re-evaluate and refine existing geomorphological maps (e.g. Traczyk 2009), extending to terrains never subject to detailed geomorphological analysis. Applications of LiDAR data have been manifold, from visual interpretation of shaded relief maps, through topographic profiling, to regional geomorphometric analysis (Kasprzak, Traczyk 2011, Traczyk, Kasprzak 2012). The purpose of this paper is to review selected examples of how the availability of LiDAR data helped to re-interpret landforms and patterns of their evolution. It is intended partly as a review/summary paper, in which we will refer to materials previously published in local journals, and almost exclusively in Polish. However, we also use this opportunity to comment on certain limitations in using LiDAR data, and to discuss research challenges and perspectives. 


\section{Study area - potential for LiDAR-based studies in geomorphology}

\section{General characteristics}

The Sudetes are a part of a belt of middle-altitude mountains and uplands (Germ. Mittelgebirge) that stretches across Central Europe, from France through Germany, Czech Republic, to Poland. Among them, the Sudetes are the highest range, peaking at $1602 \mathrm{~m}$ a.s.l., but most of the area is located at lower elevations, between 500 and $1,000 \mathrm{~m}$ a.s.l. (Fig. 1) In terms of regional geomorphological landscape, the Sudetes are most appropriately classified as a relatively recent (late Neogene - Quaternary) horst-and-graben structure superimposed on a bedrock-controlled landscape that developed through long-term denudation during the entire Cenozoic (Demek 1975, Jahn 1980, Placek, Migoń 2007, Placek 2009, Migoń 2011). Among the rock-controlled landscapes the most characteristic are hilly topographies on granites and granodiorites, with a multitude of rock outcrops of various size - domes, tors, and boulders (Czudek et al. 1964, Migoń 1996), and tableland and cuesta landscapes on sedimentary rocks, mainly sandstones, with continuous cliff lines, towers, canyons, rock labyrinths, and hoodoo rocks (Vítek 1979, Pulinowa 1989, Migoń, Placek 2007).

While the gross geomorphic features are the outcome of protracted landscape evolution (Jahn 1980), the majority of medium-scale landforms are products of Pleistocene morphogenesis under cold climatic conditions. In the most elevated parts of the Sudetes local glaciers existed and left their morphological imprint in the form of cirques and moraines (Traczyk 1990, Engel 2007, Engel et al. 2011), whereas bedrock cliffs, block fields, mid-slope benches (cryoplanation terraces), superimposed solifluction sheets, and relict patterned ground are the testimony of periglacial environment (Martini 1969, Czudek 1997, Traczyk, Migoń 2003, Krrížek et al. 2010). Landform inventory for the Sudetes includes also features resulting from mass movement, such as debris flows (Pilous 1973, Migoń, Parzóch 2008) and landslides of various types (Migoń et al. 2002, 2010).

The altitude of most individual mountain ranges within the Sudetes is not sufficiently high for them to rise above the tree line, which runs at $1,200-1,250 \mathrm{~m}$ a.s.l. (Treml et al. 2006), and the natural land cover is predominantly forest. In the Sudetes, very small areas in the Karkonosze Mts and Hrubý Jeseník Mts are located in the subalpine zone, with dwarf pine stands and grasslands; otherwise the mountains are densely forested, unless the forest was

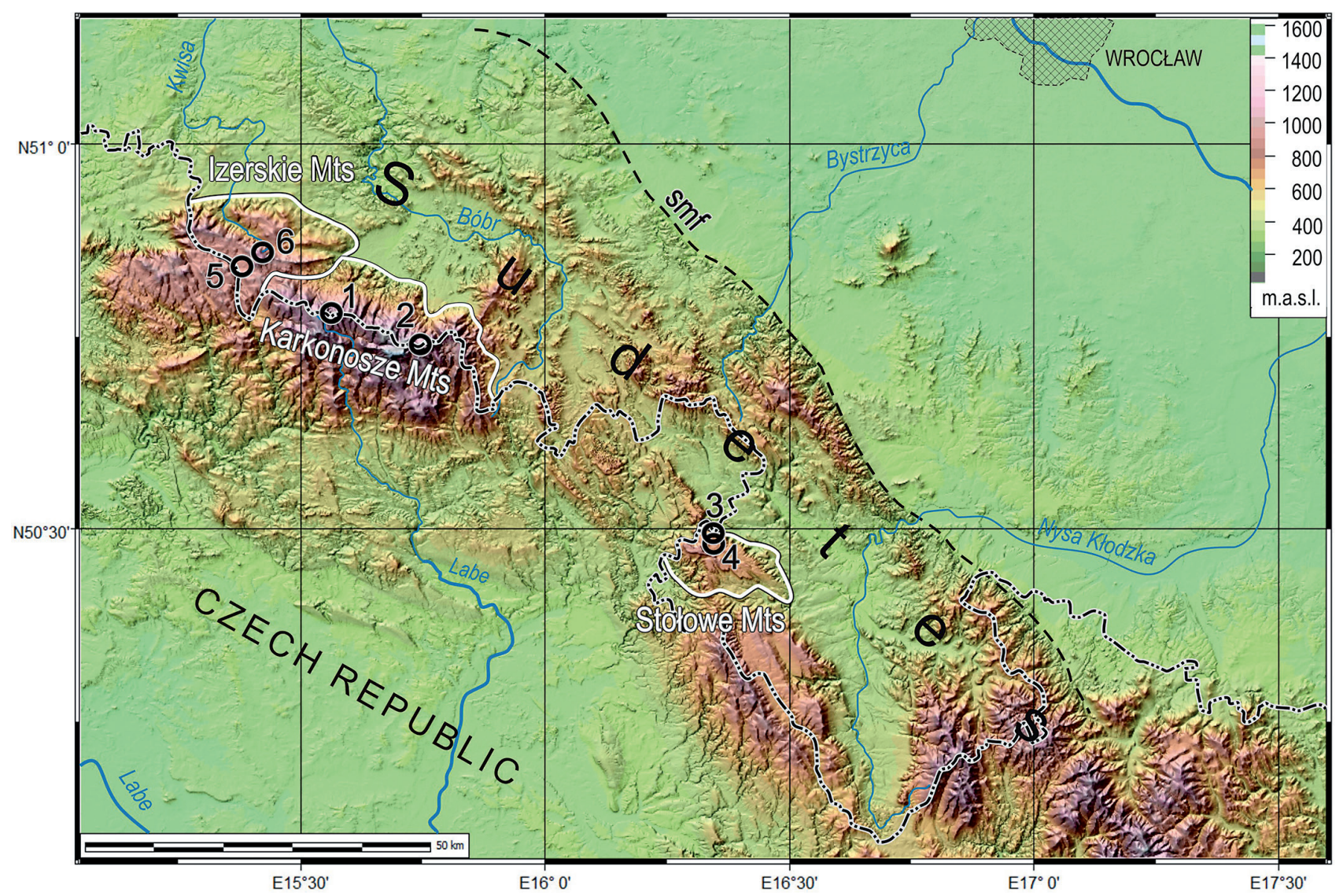

Fig. 1. Location of mountain terrains studied using LiDAR data within the Sudetes. White solid lines indicate the spatial coverage of LiDAR. smf - Sudetic Marginal Fault

Study areas referred to in detail: 1 - Śnieżne Kotły glacial cirques, 2 - Mt Śnieżka, 3 - Biała Skała escarpment, 4 - Mt Szczeliniec Wielki, 5 - Izera valley, 6 - Mt Wysoka Kopa 
cleared by humans to make room for agricultural and pastoral development. The widespread occurrence of forest cover bears on the efficacy of geomorphological mapping and limited usefulness of traditional data sources about local topography, such as topographic maps and aerial photographs.

\section{History of research}

The Sudetes have a long history of geomorphological research, the beginnings of which date back to the 1880 s and involved mapping glacial landforms and deposits in the Karkonosze Mts (then Germ. Riesengebirge) (Partsch 1882). Soon after, in the early $20^{\text {th }}$ century, further research topics emerged such as relationships between geology and relief (Cloos 1925, Berg 1927), cold-climate legacy in the most elevated parts of the Sudetes (Flohr 1934, Büdel 1937), the origin of river gorges (Berg 1928, Zeuner 1928), and landform evolution history recorded in planation surfaces (Ouvrier 1933). These research directions were continued by Polish geomorphologists after 1945 and significant advances have been made in several fields. In the Karkonosze Mts the extent of Pleistocene glaciers and the relative chronology of glaciations were established (Traczyk 1989, Chmal, Traczyk 1999), while the focus on cover deposits and residual mid-slope landforms helped to understand the patterns of hillslope evolution in the periglacial environment (Jahn 1969, Traczyk 1995, Żurawek 1999, Traczyk, Migoń 2003). In granite areas the diversity of residual granite morphology was appreciated, including its association with the phenomenon of deep weathering of granite (Jahn 1962, Migoń 1996, 1997). In the sandstone tableland of the Stołowe Mts a significant role of structural control on landforms and processes was demonstrated (Pulinowa 1989). Finally, the impact of Quaternary tectonics on the evolution of fluvial and terrace systems, particularly along the mountain front of the Sudetes, was revealed (Krzyszkowski, Pijet 1993, Krzyszkowski et al. 2000).

Most of those research exercises were based on field landform mapping, occasionally aided by an interpretation of aerial photographs. Landform distribution sketches at scales from c. 1:5,000 to 1:25,000 accompanied research papers, but these cartographic attachments were inevitably rather coarse, with insufficient detail and the obvious lack of georeferencing. Often the occurrence of individual landforms was marked by symbols placed in approximate locations, and mapping boundaries of terrain (geomorphic) units lacked objective, quantitative background. Geomorphometric approach to characterize landforms was used sporadically and typically at a regional rather than local scale (Sroka 1997, Krzyszkowski, Olejnik 1998, Badura et al. 2003). The advent of digital elevation models in the early 2000s allowed for regional analysis of various morphometric parameters and indices (Placek et al. 2007, Migoń et al. 2009) but the horizontal resolution of the source data $(25 \times 25 \mathrm{~m}, 30 \times 40 \mathrm{~m})$ was too low to capture details of hillslope or valley floor morphology.

\section{Potential for LiDAR-based studies}

Airborne high-resolution LiDAR data about surface topography are an invaluable source of information for geomorphology, which otherwise is extremely difficult, or impossible to extract. In the mountainous terrain of the Sudetes, due to dense forest cover and undergrowth, medium and small-size landforms often escape attention during field mapping and the existing topographic maps, despite their apparently fine scale $(1: 10,000 ; 1: 25,000)$, usually fail to reveal them. Likewise, widely and freely available DEMs such as SRTM-3 or ASTER GDEM are too coarse for mapping elementary landforms (Fig. 2). Errors associated with the use of GPS in measuring both height and position of single objects can also be substantial. A clear picture of spatial distribution of elementary landforms (e.g. gullies, tors) and certain topographic features (e.g. slope breaks) is even more problematic to obtain. Identical comments are valid for the dwarf pine belt above the tree line, where many interesting geomorphic features (block slopes, solifluction lobes, rock glaciers, moraines) are located.

\section{Data sources and methods}

LiDAR data used in geomorphological research in the Sudetes were acquired through airborne laser scanning that involved scanning point density of 2-7 points per
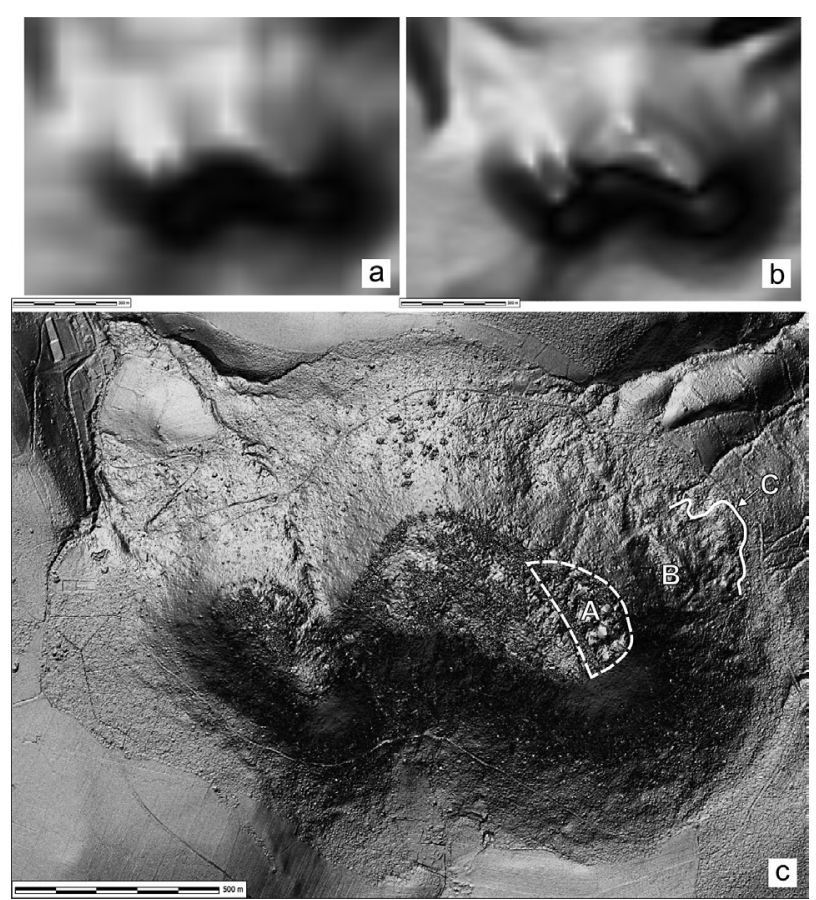

Fig. 2. Shaded relief models of Mt Szczeliniec Wielki (Stołowe Mountains) in three different resolutions, from different data sources

a - SRTM-2 (c. $60 \times 90$ m), b - DTED-2 (c. $30 \times 35$ m), c - LiDAR $(0.6 \times 0.6 \mathrm{~m})$

A - sagged eastern corner of the mesa, B - head scarp of the landslide, $\mathrm{C}$ - landslide toe 
$1 \mathrm{~m}^{2}$ and measurement accuracy $0.15-0.25 \mathrm{~m}$. Rough data were models of 'bare Earth' type and contained information about altitude of the topographic surface at a point, recorded as sectional .LAS or .XYZ files. ASL was independently commissioned by several state institutions to enrich their Geographic Information Systems and help current land management. These included the Karkonosze National Park, the Góry Stołowe National Park, and Świeradów Forest Inspectorate. The resolution of digital elevation models used in geomorphological analysis was, depending on specific research targets, from $0.6 \times 0.6 \mathrm{~m}$ to $5 \times 5 \mathrm{~m}$ and these very fine models proved invaluable in landform recognition. Modelling of geomorphometric parameters for larger areas required resolution change to $10 \times 10 \mathrm{~m}$ and $30 \times 30 \mathrm{~m}$.

Further work involved the use of various software within GIS environment. Data preparation was performed using Global Mapper (conversion of file formats, change of cartographic reference system, model re-interpolation, generation of contour lines). For terrain visualization and quantitative analysis of surface topography, Open Source software/GIS packages such as SAGA GIS and MicroDEM were applied. Both have been found particularly suitable for geomorphometric analyses due to abundance of tools to handle raster digital models.

Basic and derivate land-surface (e.g. primary and secondary) parameters were widely used in the analytical studies. Among the basic parameters, elevation and slope are used most often. More in-depth interpretation was possible due to the implementation of such derivate parameters as Relief, Convergence Index (CI), Topographic Wetness Index (TWI), and Topographic Position Index (TPI) (Wilson, Galant 2000, Conrad 2001, Guth 2003, 2009, Olaya, 2004, Sørensen et al. 2005, MacMillian, Shary 2009, Olaya, Conrad 2009). In addition, algorithms to automatically detect relief lineaments (Topographic Grain) were used (Guth 2009).

\section{Karkonosze Mountains - glacial and periglacial landforms revisited}

The Karkonosze Mountains, the highest mountain massif within the Sudetes, are the area for which LiDAR data were made available at earliest, in the late 2000s. The spatial pattern of major landforms has long been known and usually explained in terms of differential uplift of an old surface of low relief followed by bedrock-controlled fluvial erosion, locally enhanced by glacial action (Berg 1927, Sekyra 1964). Gross relief features were adequately revealed by the existing small-scale topographic maps $(1: 50,000 ; 1: 25,000)$, but the coarseness of contour line presentation seriously limited our ability to identify and map assemblages of minor landforms of glacial and particularly, periglacial origin, often hidden by forest stands and dwarf pine communities. It was somehow paradoxical that despite an extensive research focused on cold-climate geomorphic legacy (e.g. Sekyra 1961, Jahn 1963, 1968), attempts of systematic geomorphological mapping of periglacial features (frost-riven cliffs, solifluction tongues, sorted circles and stripes) have not been made until the 1990s. On a few landform maps from that time their occurrence was indicated schematically and symbolically, without precise location (Cielińska 1961, Sekyra 1964).

The availability of LiDAR data, along with ortophotomaps and advances in GIS techniques, has opened new opportunities for landform mapping. The prime example of using this opportunity is the recent research on glacial depositional terrain on the northern slope of the Karkonosze. Both the Łomnica valley and the forefield of Śnieżne Kotły (= Snowy) cirques were investigated in 1980s and 1990s, through field mapping and interpretation of aerial photographs at $1: 15,000$ and $1: 16,000$ scale, resulting in maps showing the extent of glaciated terrain as a whole, as well as the course of individual moraine ridges and the presence of selected landforms of non-glacial origin (Traczyk 1989, Chmal, Traczyk 1999; Fig. 3A).

The maps from the late $20^{\text {th }}$ century were subject to verification using DEM and shaded relief images derived from LiDAR data, by means of on-screen vectorization technique (Traczyk 2009, Traczyk, Woronko 2010). Findings from the new picture for the Śnieżne Kotły area (Fig. 3B) include the following:

- in the younger phase of glaciation the extent of glaciers was probably larger than before and the older moraine ramparts may have been overridden by ice tongues, which extended further to the north-east (Fig. 3C). Today, these older ridges appear to emerge from below the younger depositional terrain. Before, it was suggested that every more recent glacial advance was of shorter extent.

- a relict system of meltwater channels was recognized behind the most distant moraine complex.

- an arcuate hollow within the outer moraine rampart, along with a hummocky ground further downslope, is interpreted as a relict landslide (slump) on the steep flank of the moraine. Widespread landsliding on flanks of terminal moraines is a phenomenon known from many glacierized terrains.

- an apparently chaotic suite of humps, ridges and closed depressions in the floor of the Mały Śnieżny Kocioł cirque resembles landform assemblages left by the decay of a rock glacier. It would have been a glacier-derived rock glacier, formed in the period of advanced deglaciation.

High-resolution elevation data helped in detailed mapping of periglacial landforms too. The effects of research in the western part of the Karkonosze have been reported elsewhere (Traczyk 2007), while Fig. 4 presents the results of periglacial landform mapping on the eastern slope of Mt Śnieżka. The analysis of dense contour map allowed to delimit the extent of mid-slope benches, cryoplanation flats, snowpatch hollows and debris lobes indicating solifluction processes. The previously available ortophotomap, despite its very high 



resolution of $0.15 \times 0.15 \mathrm{~m}$, proved inadequate to carry out this exercise because of the effect of vegetation and the occurrence of various anthropic landforms resulting from the long history of human presence in the summit part of Mt Śnieżka.



Fig. 3. Past and updated interpretation of the glacial morphology in the front of Śnieżne Kotły cirques

A: Moraine succession after Chmal, Traczyk (1999, modified): 1, 2, 3 - moraine ridges of zones I, II, III (compare with Fig. 3C), 4 - glacial deposition zone from the oldest (?) glaciation of the Śnieżne Kotty, 5, 6, 7 -glacial accumulation domain of zones I, II, III, respectively, 8 - edges of glacial cirques, 9 - summit planation surface, 10 - lakes, 11 - contours every 50 m, 12 - glacial stages after Chmal, Traczyk (1999)

B: Glacial morphology of the Śnieżne Kotty on the basis of topographic maps analysis and LiDAR data (after Traczyk 2009): 1 - edges and cirque walls, 2 - rock slopes within cirque walls, 3 - moraines from the oldest glaciation phase, 4 - moraines from the younger phase of glaciation, 5 -moraines from the youngest phase of glaciation, 6 - crests of moraine ridges, 7 - ridge and hollows morphology (rock glacier?), 8 - ancient meltwater channels, 9 - debris-blocky periglacial slope cover

C: Reinterpretation of glacier extent based on Fig. 3B and DEM analysis: 1 - cirque walls, 2, 3, 4 - successive phases of glaciation (I, II, III) and recessional phases (Ia, IIIa - IIId), 5 - probable rock glacier, 6 - block fields. MKS - Mały Kocioł Śnieżny cirque, WKS - Wielki Kocioł Śnieżny cirque

\section{Stołowe Mountains - patterns of mass movement revealed}

The uniqueness of the Stołowe Montains as the only elevated tableland on sedimentary formations in Poland 


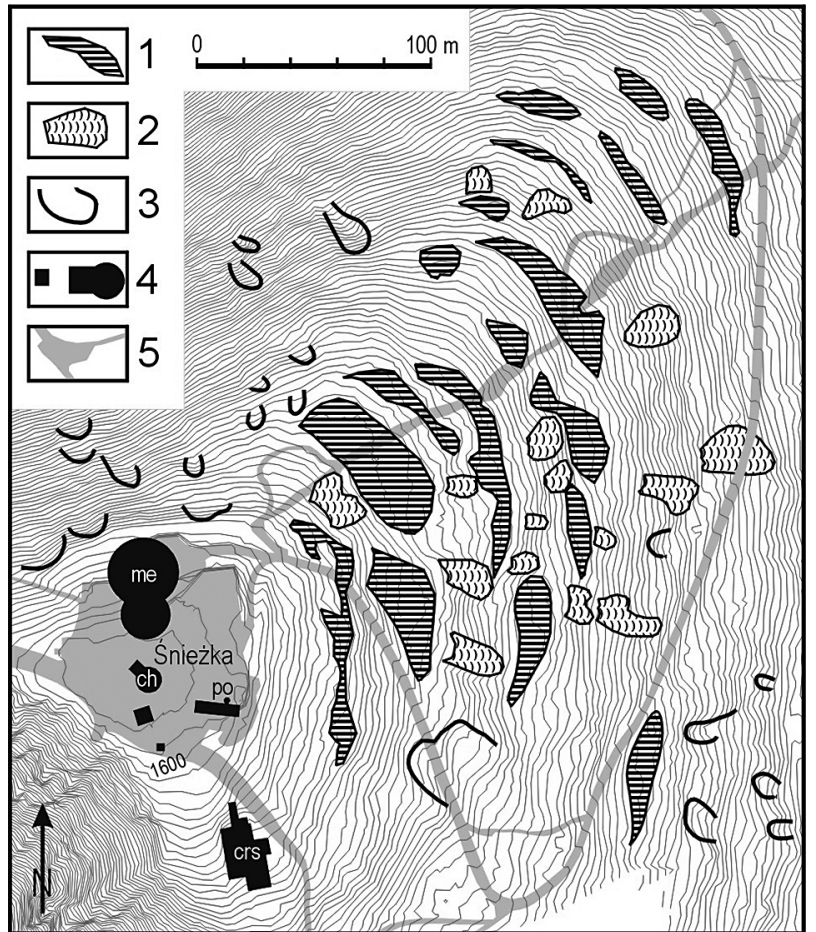

Fig. 4. Periglacial landforms on Mt Śnieżka

1 - cryoplanation terraces, 2 - solifluction lobes, 3 - nivation hollows, 4 - buildings, 5 - roads; me - meteorological station, ch - chapel, po - post office, crs - cable car station. Contour lines every $1 \mathrm{~m}$
(Fig. 5) has long been recognized (Czeppe 1952), but the first comprehensive study of their geomorphology was attempted in the 1970/80s (Pulinowa 1989). Long-term escarpment retreat was widely accepted as one of principal means of landscape evolution but the specific mechanisms involved remained elusive. Sandstone-capped escarpments were explained in terms of a classical model of a concave slope, with free face, debris slope, and wash slope occurring in a downslope succession (Dumanowski 1961).

A new digital elevation model based on LiDAR data has revealed that the surface topography of the middle and toe slopes below the sandstone precipices is significantly more complex than assumed before (Migoń, Kasprzak 2011, 2012, Migoń et al. 2011, Kasprzak 2013). Detailed slope profiles are not consistently concave but contain alternating benches and steeper sections, often terminating in distinct bulges in the lower slope. Hence, the topography is wavy rather than planar, with superimposed large sandstone boulders, some as big as 5-6 m. The steps (risers) are rarely straight; more commonly, they follow sinuous courses, locally with lobes projecting downslope alternating with embayments. Such a topographic pattern has been described in detail below the spur of Biała Skała within the northern escarpment (Migoń, Kasprzak 2012),

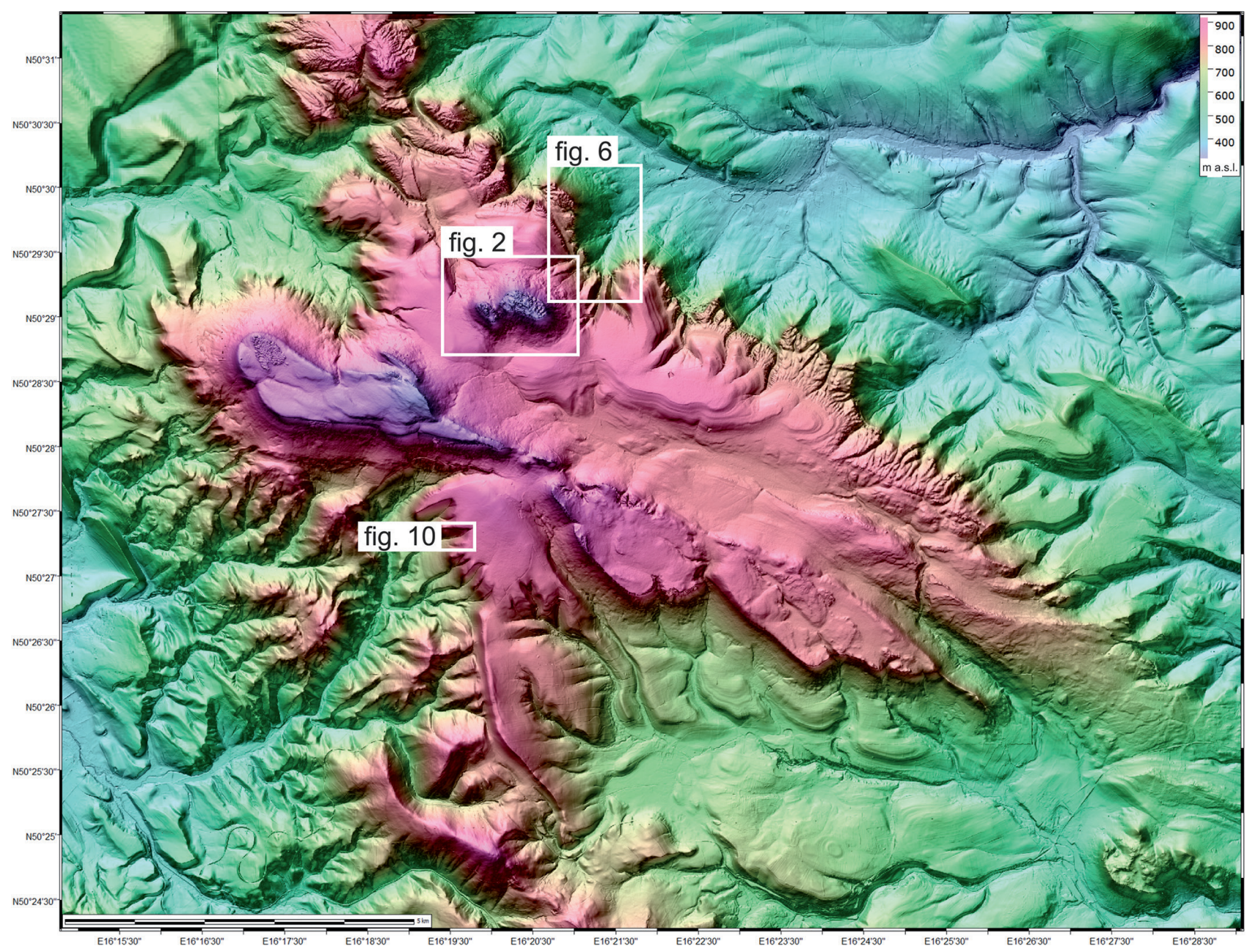

Fig. 5. Main features of the sandstone tableland of Stołowe Mountains on LiDAR-derived DEM 


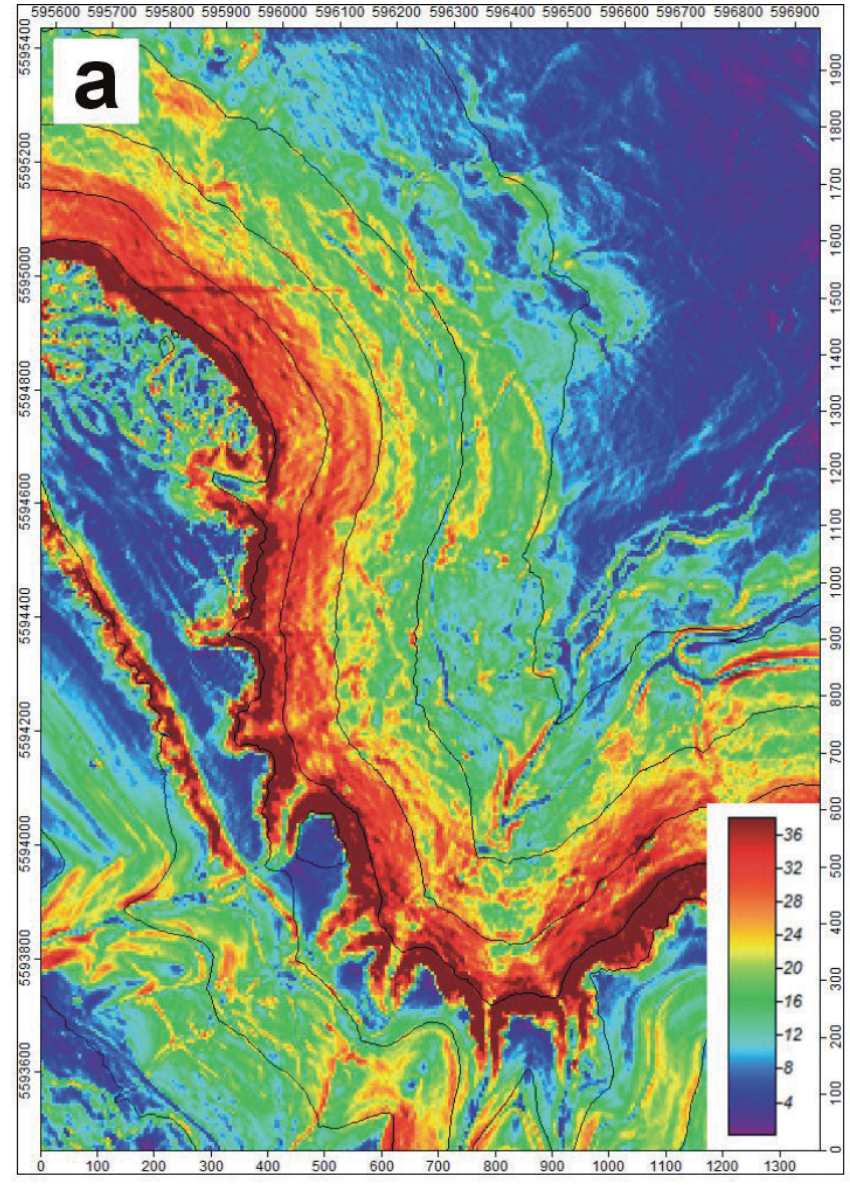

N50.5035591" E16.3469182"

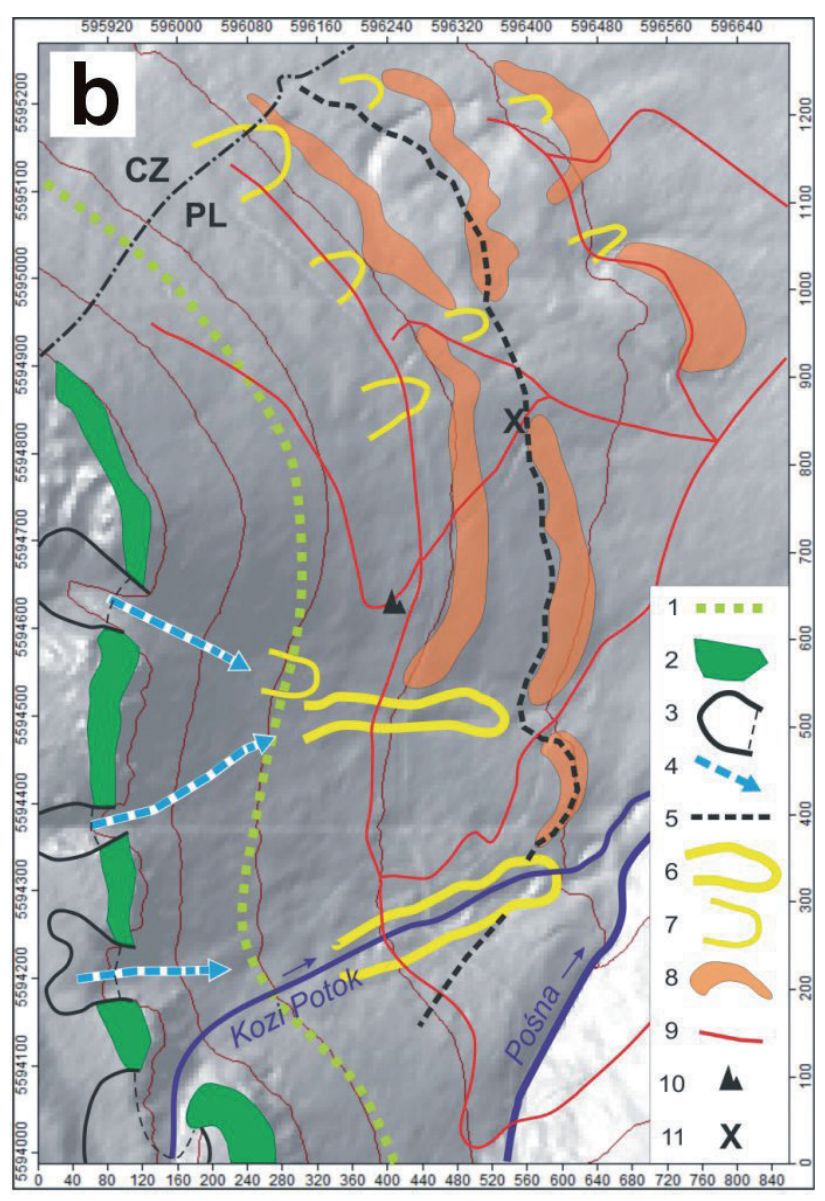

N50.5031780 E16.3664550

\section{C}

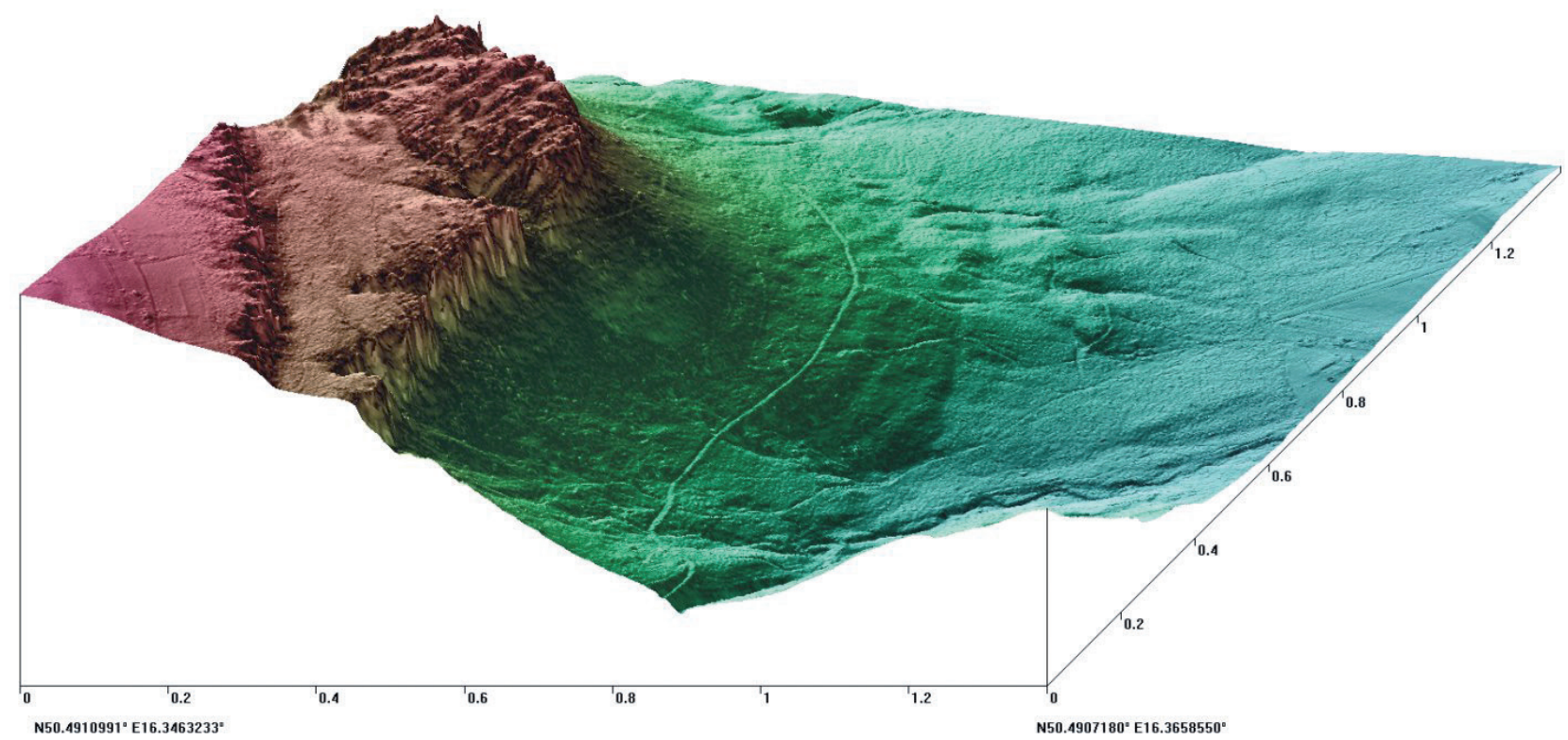

Fig. 6. Escarpment topography affected by mass, Biała Skała, Stołowe Mountains

a - slope map in degrees derived from $1 \times 1$ m LiDAR DEM, $\mathrm{b}$ - geomorphological interpretation, $\mathrm{c}$ - visualization (a, b - after Migoń, Kasprzak 2012) Explanation to b: 1 - Permian/Cretaceous boundary, 2 - sandstone rock faces, 3 - hanging valleys, 4 - drainage lines, without permanent streams, 5 - lower boundary of continuous block cover, 6 - boulder streams, 7 - minor boulder lobes, 8 - landslide frontal scarps, 9 - roads, 10 - isolated rock outcrop, 11 - colluvium outcrop

but it occurs elsewhere too. DEM analysis supported by subsequent field inspection has led us to the interpretation of this landform assemblage as a series of overlapping shallow translational landslides and earth flows (Fig. 6). Hillslope instability was initiated within the lower slope segment, underlain by Permian sedimentary formations 


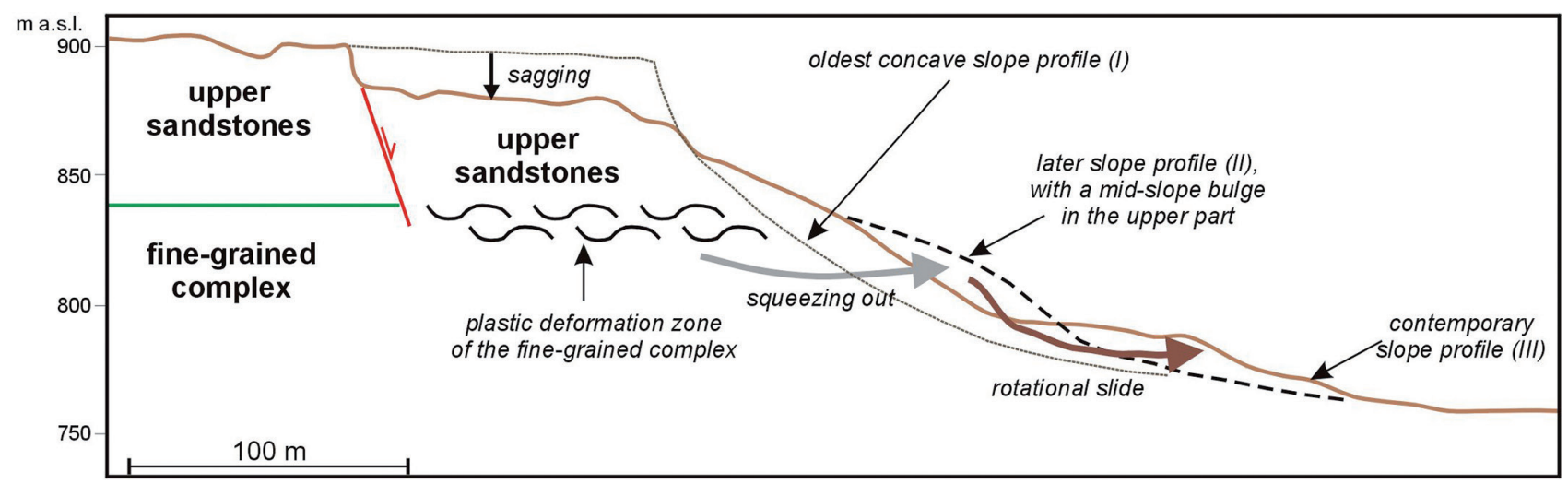

Fig. 7. Interpretation of the mass movement sequence on the eastern slopes of Mt Szczeliniec Wielki (after Migoń, Kasprzak 2011, modified)

(conglomerates, sandstones, mudstones), and propagated upslope, into the Cretaceous. The presence of large sandstone boulders far away from the caprock needs not to be explained by long run-out rock falls but can be plausibly explained by their passive transport atop sliding masses, as on a conveyor belt.

LiDAR proved also immensely useful to decipher the style and probable succession of mass movements on the slope of the mesa of Mt Szczeliniec Wielki (919 m), the highest peak in the Stołowe Mountains. Dumanowski (1961) and Pulinowa (1989) pointed to the north-eastern sector of the mesa as subject to the most widespread deformation, but were unable to provide map details. Ongoing instability along the mesa rim has been confirmed by precise geodetic surveying (Košták, Cacoń 1988, Cacoń et al. 2010). DEM of $1 \times 1 \mathrm{~m}$ resolution revealed a range of specific topographic features (Fig. 2c) which together combine into a coherent story (Migoń, Kasprzak 2011). First, the north-eastern corner of the mesa, accounting for c. 1/6 of its total surface, is lowered by 15-20 $\mathrm{m}$. A straight topographic step separates the downthrown part from the main plateau. Furthermore, within this lowered portion the sandstone cap is no longer one rock mass.



Fig. 8. Shaded relief model of the Izera valley, Izerskie Mountains
It has broken down into a chaos of huge blocks, more than $10 \mathrm{~m}$ long and high, with large caverns between and below them. Second, a distinct arcuate scarp occurs in the mid-slope immediately below the NE part of the mesa, with slope inclination up to $45-48^{\circ}$, whereas the adjacent slope is only $20-30^{\circ}$. Third, in the lower slope sector a series of lobate risers up to $8 \mathrm{~m}$ high, covered with large sandstone blocks, extends along c. $300 \mathrm{~m}$ perpendicular to the slope.

This geomorphic pattern has been interpreted as follows (Fig. 7). Subsurface denudation at the sandstone/ mudstone and marl boundary, both physical and chemical (Pulinowa 1989), resulted in the removal of support for the sandstone cap and sagging of the north-eastern part of the mesa. This induced deformation of the underlying fine-grained formations which were squeezed out, leading to slope steepening, apparently beyond the limits of stability. In consequence, the oversteepened mid-slope failed leaving an arcuate scarp, interpreted as a head scarp of a rotational slide which transformed into an earth slide below. Topography suggests that minor slides of this type occurred next to the main slide. Displaced rock masses came to rest at the footslope (Migoń, Kasprzak 2011).

\section{Izerskie Mountains}

Izerskie Mountains, built of granite in the southern part and gneiss in the northern part, are located in the western part of the Sudetes. Gross topographic features include parallel ridges of WNW- ESE extension, separated from one another by fault-controlled valleys (Oberc 1975, Migoń, Potocki 1996). Specific morphology has developed in the central part of the uplifted block, where a large intramontane basin at c. $830 \mathrm{~m}$ a.s.1. exists, with a nearly level floor occupied by peat bogs and the wide meandering valley of the Izera river. Until recently, geomorphology of the Izerskie Mountains has remained relatively under-researched and poorly understood. LiDAR data, covering the highest parts of the mountain terrain, were first used to detect forest health conditions and damage inflicted by flooding (Strzeliński 

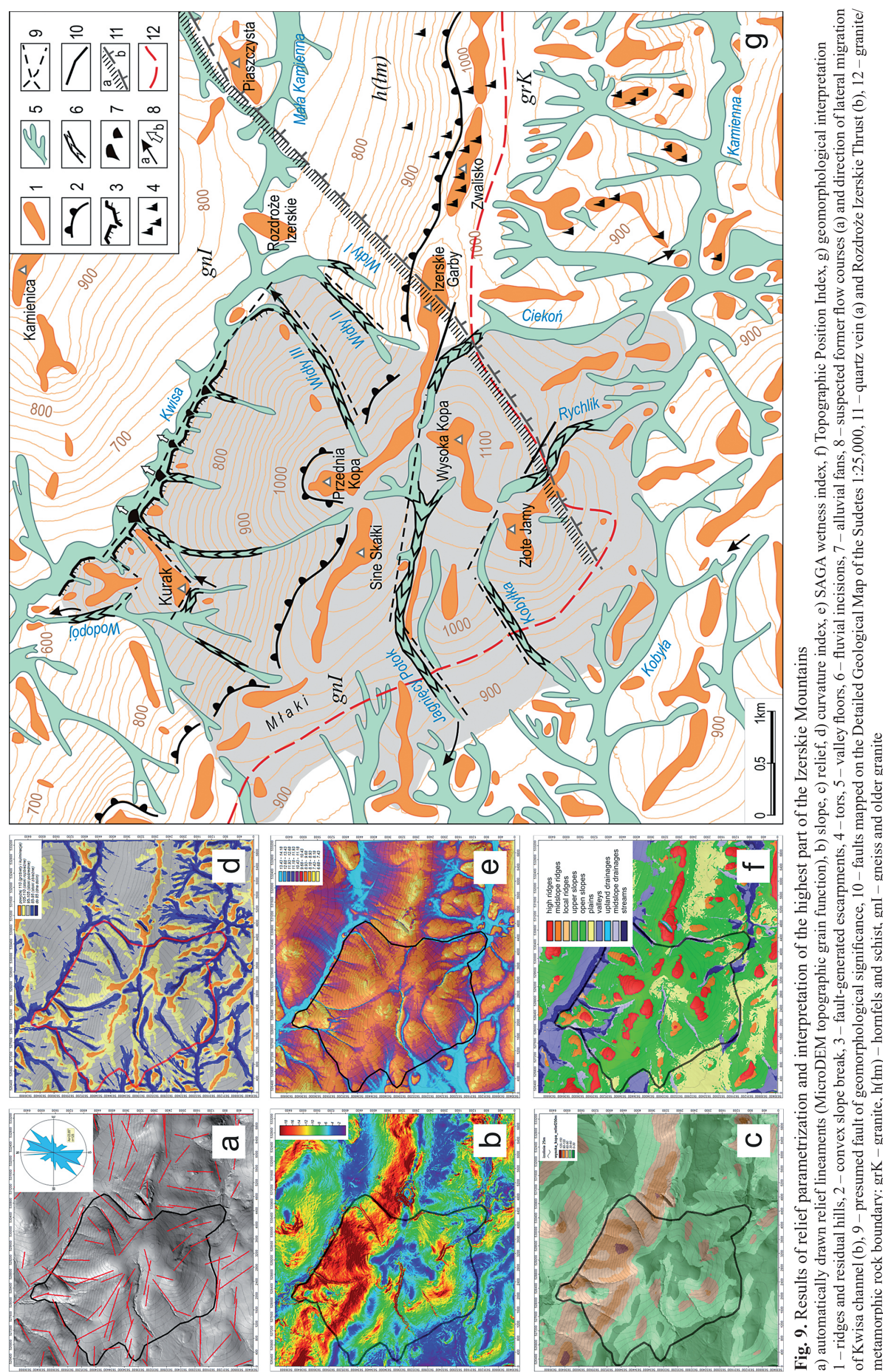
et al. 2008). Later, very high resolution of bare Earth digital elevation models allowed for detailed mapping of fluvial morphology along the Izera river (Fig. 8) and the recognition of unit reaches with dissimilar erosional and depositional channel features and terrace systems (Kasprzak, Traczyk 2010). In particular, active and abandoned channels of the Izera river and its tributaries, as well as gravel bars, can be recognized, and an opportunity emerges to map the extent of palaeomeanders and their spatial relationships. LiDAR models helped in precise recording of morphometric parameters of meanders, which vary from $13.4 \mathrm{~m}$ to $58.5 \mathrm{~m}$, their downstream change, the height of bank undercutting, and the width of terrace levels. Digital elevation models analysed in conjunction with ortophotomaps from different years helped to record and quantify changes in gravel bar dimensions and channel migration. As a final effect, reaches typified by different morphodynamic conditions were recognized (Kasprzak, Traczyk 2010).

Spatial analysis of parameters derived from LiDAR-based elevation models have also allowed us to recognize local relief lineaments (topolineaments) and locate $1^{\text {st }}$ order watercourses, suspect to reflect minor tectonic zones and then subject to statistical analysis of predominant directions (Traczyk, Kasprzak 2012). Further components of the analysis included characterization of slope asymmetry, recognition of slope breaks, evaluation of slope shapes, and automatic classification of landforms. To detect possible fault-controlled topographic features an analysis of Topographic Wetness Index parameter has proved particularly useful. It helped to recognize linear depressions connecting headwater valleys with saddles within water divides, indicating that fluvial erosion exploits zones of structural weakness. These topographic concavities are often perpendicular to one another, further suggesting bedrock control. Other landforms to note are convex elevations and deeply incised V-shaped valleys dissecting mid-slopes, which may be interpreted as the fluvial response to ongoing uplift (Fig. 9).

\section{Limitations, challenges and perspectives for future research}

Although it is evident that LiDAR-based digital elevation models have substantially increased our ability to recognize landforms and their spatial patterns in the forested terrain, one should not be uncritical towards LiDAR. Confrontation of image analysis (shaded relief models, slope gradient maps) with ground check during field surveys has revealed several limitations of LiDAR data. In a difficult terrain, steep and covered by dense forest stands, topographic details are not adequately captured even if the preset density of measured points is 3-4 per $1 \mathrm{~m}^{2}$. For instance, in the Stołowe Mountains LiDAR-derived models failed to return clusters of large (3-4 m long) sandstone boulders in a deeply incised ravine below Mt Rogowa Kopa (Fig. 10), whereas boulders of similar size can be identified elsewhere, on a flat ground. Surface morphology of the sagged eastern portion of the mesa of Mt Szczeliniec Wielki (see section 5) has not been returned either. Thus, the absence of minor elements of relief in specific places on LiDAR images is not necessarily the evidence of absence in reality and hence, conclusions about landform spatial distribution may not be correct. In the Karkonosze Mountains too, 4-6 m appears as a size threshold limit for safe identification of individual landforms, which leaves granite residual boulders, details of blockslopes, minor erosional landforms and minor anthropic elements below the limit. On the other hand, linear features usually appear very clearly even if the depth and width are of the order of 1-2 m (e.g. drainage ditches, risers of agricultural terraces, minor erosional incisions, crests of moraine ramparts). In areas above the timberline and stripped of forest orthophotomaps are indispensable and interactive tools to draw topographic profiles prove most useful. In the dwarf pine belt, which includes significant portions of the flat summit surface, artifacts left after removal (filtering out) of dwarf pine stands may be of similar size and shape as some minor relief features observed on peat bog surfaces (Klementowski 2008). An important comment here is that the accuracy of LiDAR
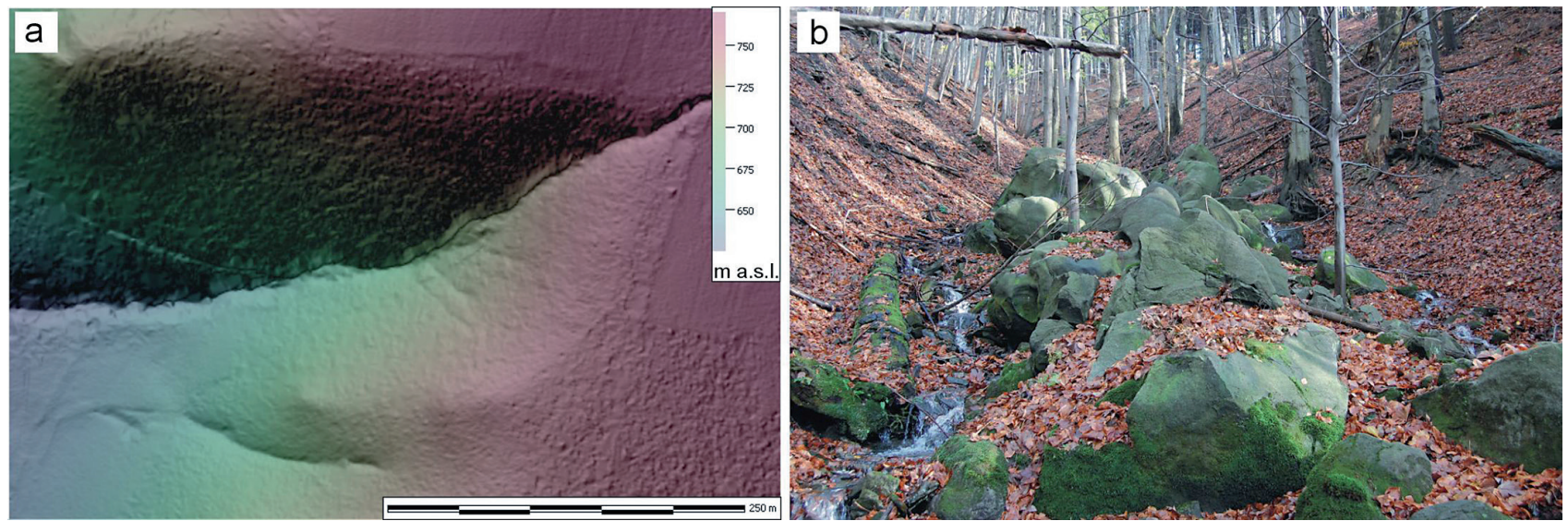

Fig. 10. Comparison of shaded relief model based on LiDAR data for a deeply incised valley and a ground photograph; the cluster of big sandstone boulders, despite their size, is not visible on the LiDAR image 
data in all our exercises was beyond our control, as databases were acquired from external sources.

Our experience also tells us that an increased resolution does not necessarily mean more information. Submetric resolution proves very helpful in the recognition of minor landforms and their relation to local bedrock controls, but introduces too much information noise if more regional patterns are the focus of research. For relief parametrization we usually re-interpolate elevation models to $10 \times 10 \mathrm{~m}$ resolution or less. This data preparation allows us to remove small surface features which are not relevant to the scope of the analysis (e.g. single boulders, minor steps in slope morphology, model imperfections, mainly in forest areas), makes it possible to reduce the size of a dataset and speeds up geomorphometric calculations to obtain a synthetic result of landform parameterization at a regional scale. An issue closely related to the volume of data is computational power of PCs which may not be sufficient to handle large datasets effectively. For example, the size of DEM (.ASC file) in $1 \times 1 \mathrm{~m}$ resolution $(1,612$ columns, 1,350 rows) used to create Fig. 9 is $16,350 \mathrm{kB}$, while the reduction of resolution to $5 \times 5 \mathrm{~m}$ (322 columns, 270 rows) yielded a $704 \mathrm{kB}$ file, and further reduction to $10 \times 10 \mathrm{~m}$ (161 columns, 135 rows) only a $176 \mathrm{kB}$ file. Thus, the size of files decreases exponentially.

Perspectives for further research using airborne LiDAR are very promising. Since early 2013, LiDAR data are widely available at reasonable cost, due to the implementation of ISOK programme. Although the coverage of the territory will not long be complete, critical areas such as mountainous terrains, large river valleys and major cities are or will soon be covered. This opens new opportunities for landform recognition, especially in difficult terrains such as the Sudetes, and may generate new interest in regional geomorphological mapping. Likewise, LiDAR data will be an invaluable addition to the geomorphological toolkit in a range of specific problems.

\section{Conclusions}

The long history of geomorphological research in the Sudetes, within which landform mapping was an important component, might generate an impression that any contribution to landform recognition would be minor. This has proved incorrect. The arrival of high-resolution LiDAR data, which can be used to create detailed digital elevation models and to carry out advanced geomorphometric analysis, has opened new avenues of research and provided solid basis to re-evaluate landforms known before. The ability of LiDAR to remove vegetation before further analysis is particularly useful in densely forested terrains such as the Sudetes. Recent advances arising from the use of LiDAR include landform-based reinterpretation of local glacial history in the Karkonosze Mountains, refinement of periglacial landform inventories, deciphering patterns of mass movements along sandstone capped escarpments in the Stołowe Mountains, recognition of complex fluvial morphology of mountain valleys, and new morphotectonic interpretations. However, as far as possible, image interpretation should be verified in the field. Despite theoretical capability of LiDAR-derived models to show even landforms $1-2 \mathrm{~m}$ in length/height, 4-6 $\mathrm{m}$ seems the more realistic threshold size unless these landforms are distinctly linear and continue over long distances. Thus, the absence of certain surface features on LiDAR images should not be automatically explained that they do not exist.

\section{Acknowledgements \\ We thank the Karkonosze National Park, the Stołowe Mountains National Park, and the Świeradów Forest Directorate for granting ac- cess to their LiDAR topographic data. Research reviewed in this paper was carried out within the framework of research projects NR09-0029- 04/2008 (led by Tadeusz Chodak) funded by the Committee of Scientific Research and 1015/S/IGRR - the statutory project of the Department of Geography and Regional Development, University of Wrocław.}

\section{References}

Badura J., Zuchiewicz W., Górecki A., Sroka W., Przybylski B., 2003. Morfometria strefy sudeckiego uskoku brzeżnego między Złotym Stokiem a Dobromierzem. Przegląd Geologiczny 51: 1048-1057.

Berg G., 1927. Zur Morphologie des Riesengebirges. Zeitschrift für Geomorphologie 2: 1-20.

Berg G., 1928. Einige grundsätzliche Bemerkungen zu den erscheinungen der nordischen Vereisung am Sudetenrande. Zeitschrift der deutschen geologischen Gesellschaft 80: 215-224.

Bishop M.P., 2013. Remote sensing and GIScience in geomorphology: Introduction and overview. In: J. Shroder (editor in chief), M.P. Bishop (ed.), Treatise on Geomorphology. Vol. 3. Remote Sensing and GIScience in Geomorphology. Academic Press, San Diego: 1-24.

Borkowski A., Perski Z., Wojciechowski T., Jóźków G., Wójcik A. 2011. Landslides mapping in Roznow Lake vicinity, Poland, using Airborne Laser Scanning data. Acta Geodynamica et Geomaterialia 8(3): 325-333.

Büdel J., 1937. Eiszeitliche und rezente Verwitterung und Abtragung im ehemals nicht vereisten Teil Mitteleuropas. Petermanns Geographische Mitteilungen. Ergänzungsheft 229: 5-71.

Cacoń S., Kapłon J., Kontny B., Weigel J., Švábenský O., Kopecký J., 2010. Recent local geodynamics in the central part of the Stołowe Mts. Acta Geodynamica et Geomaterialia 7, 3(159): 335-342.

Chmal H., Traczyk A., 1999. Die Vergletscherung des Riesengebirges. Zeitschrift für Geomorphologie, N.F., Suppl.-Bd. 113: 11-17.

Cielińska M., 1961. Map of periglacial covers in the western part of the Karkonosze. In: Guide Book of Excursion B, The Sudetes. VIth INQUA Congress, Łódź.

Cloos H., 1925. Einführung in die tektonische Behandlung magmatischer Erscheinungen (Granittektonik). Teil I. Das Riesengebirge in Schlesien. Berlin: 194 pp.

Conrad O., 2001. Convergence Index, Wiki Documentation. Online: http://sourceforge.net/apps/saga-gis/wiki/ta_morphometry_1-saga-gis - 2012.01.02.

Czeppe Z., 1952. Z morfologii Gór Stołowych. Ochrona Przyrody 20: 236-254.

Czudek T., 1997. Reliéf Moravy a Slezska v kvartéru. Sursum, Tišnov: 213 pp.

Czudek T., Demek J., Marvan P., Panoš V., Raušer J., 1964. Verwitterungs- und Abtragungsformen des Granits in der Böhmischen Masse. Petermanns Geographische Mitteilungen 108: 182-192.

Demek J., 1975. Planation surfaces and their significance for the morphostructural analysis of the Czech Socialist Republic (ČSR). Studia Geographica ČSAV 54: 133-164.

Dumanowski B., 1961. Zagadnienie rozwoju stoku na przykładzie Gór Stołowych. Czasopismo Geograficzne 32: 311-324. 
Engel Z., 2007. Late Pleistocene glaciations in the Krkonoše Mts. In: A.S. Goudie, J. Kalvoda (eds.), Geomorphological Variations. Nakladatelství P3K, Prague: 269-285.

Engel Z., Traczyk A., Braucher R., Woronko B., Kř́ižek M., 2011. Use of $10 \mathrm{Be}$ exposure ages and Schmidt hammer data for correlation of moraines in the Krkonoše Mountains, Poland/Czech Republic. Zeitschrift für Geomorphologie, N.F. 55: 175-196.

Flohr E., 1934. Alter, Entstehung und Bewegungserscheinungen der Blockmeere des Riesengebirges. Veröffentlichungen der schlesischen Gesellschaft für Erdkunde 21: 395-418.

Guth P.L. 2009. Microdem help. U.S. Naval Academy.

Guth P.L., 2003. Terrain organization calculated from digital elevation models. In: I.S. Evans, R. Dikau, E. Tokunaga, H. Ohmori, M. Hirano (eds.), Concepts and Modelling in Geomorphology: International Perspectives. Terrapub Publishers, Tokyo: 199-220.

Höfle B., Rutzinger M., 2011. Topographic airborne LiDAR in geomorphology: A technological perspective. Zeitschrift für Geomorphologie 55, Suppl. 2: 1-29. http://dx.doi.org/10.1127/0372-8854/2011/0055S2-0043

Jahn A., 1962. Geneza skałek granitowych. Czasopismo Geograficzne 33: $19-44$.

Jahn A., 1963. Gleby strukturalne Czarnego Grzbietu i problem utworów pylastych w Karkonoszach. Acta Universitatis Wratislaviensis 9, Studia Geograficzne 1: 55-65.

Jahn A., 1968. Some problems concerning slope development in the Sudetes. Biuletyn Peryglacjalny 18: 331-348.

Jahn A., 1980. Main features of the Tertiary relief of the Sudetes Mountains. Geographia Polonica 43: 5-23.

Kasprzak M., 2013. The Stołowe Mountains - studies in geomorphometry and new facts about landforms. In: P. Migoń, M. Kasprzak (eds.), Sandstone Landscapes. Diversity, Ecology and Conservation. Proceedings of the $3^{\text {rd }}$ International Conference on Sandstone Landscapes, Kudowa-Zdrój (Poland), 25-28 April 2012. Instytut Geografii i Rozwoju Regionalnego Uniwersytetu Wrocławskiego, Wrocław: 77-84.

Kasprzak M., Traczyk A., 2010. Geomorfometria granitowej części Karkonoszy. Landform Analysis 13: 33-46.

Kasprzak M., Traczyk A., 2011. Rzeźba i rozwój doliny Izery w Sudetach Zachodnich. Opera Corcontica, 48: 7-34.

Knapik R., Jała Z., Sobczyk A., Migoń P., Aleksandrowski P., Szuszkiewicz A., Krąpiec M., Madej S., Krakowski K., 2009. Inwentaryzacja i waloryzacja geostanowisk Karkonoskiego Parku Narodowego i jego otuliny oraz wykonanie mapy geologicznej tego obszaru. Archive of the Karkonosze National Park (unpublished).

Kondo H., Toda S., Okumura K., Takada K., Chiba T., 2008. A fault scarp in an urban area identified by LiDAR survey: A Case study on the Itoigawa-Shizuoka Tectonic Line, central Japan. Geomorphology 101: 731-739.

http://dx.doi.org/10.1016/j.geomorph.2008.02.012

Košt'ák B., Cacoń S., 1988. Monitoring and interpretation of sandstone block movements on a table hill margin. In: Proceedings of the 5th International Symposium on Landslides, 10-15 July 1988, Lausanne. A.A. Balkema, Rotterdam: 439-442.

Křížek M., Engel Z., Treml V., 2010. Czy najwyższe partie Sudetów powyżej górnej granicy lasu są domeną peryglacjalną? Czasopismo Geograficzne 81: 75-102.

Krzyszkowski D., Olejnik W., 1998. The role of neotectonics in the Quaternary evolution of the landscape of the Sowie Mts., Sudetes, southwestern Poland. Geologia Sudetica 31: 221-239.

Krzyszkowski D., Pijet E., 1993. Morphological effects of Pleistocene fault activity in the Sowie Mountains, Sudeten, Southwestern Poland. Zeitschrift für Geomorphologie, N.F., Suppl.-Bd. 94: 243-259.

Krzyszkowski D., Przybylski B., Badura J., 2000. The role of neotectonics and glaciation on terrace formation along the Nysa Kłodzka river in the Sudeten Mountains (southwestern Poland). Geomorphology 33: $149-166$ http://dx.doi.org/10.1016/S0169-555X(99)00123-3

Lin Z., Kaneda H., Mukoyama S., Asada N., Chiba T., 2013. Detection of subtle tectonic-geomorphic features in densely forested mountains by very high-resolution airborne LiDAR survey. Geomorphology 182: $104-115$.

http://dx.doi.org/10.1016/j.geomorph.2012.11.001
MacMillian R.A., Shary P.A., 2009. Landforms and landform elements in geomorphometry. In: T. Hengl, H.I. Reuter (eds.), Geomorphometry. Concepts, Software, Applications. Developments in Soil Science 33. Elsevier, Amsterdam: 227-254. http://dx.doi.org/10.1016/S0166-2481(08)00009-3

Martini A., 1969. Sudetic tors formed under periglacial conditions. Biuletyn Peryglacjalny 19: 351-369.

Migon P., 1996. Granite landscapes of the Sudetes Mountains - some problems of interpretation: a review. Proceedings of the Geologists' Association 107: 25-38.

Migoń P., 1997. Palaeoenvironmental significance of grus weathering profiles: a review with special reference to northern and central Europe. Proceedings of the Geologists' Association 108: 57-70.

Migoń P., 2011. Geomorphic diversity of the Sudetes - Effects of global change and structure superimposed. Geographia Polonica 84, Special Issue Part 2: 93-105.

Migoń P., Hrádek M., Parzóch K., 2002. Extreme geomorphic events in the Sudetes Mountains and their long-term impact. Studia Geomorphologica Carpatho-Balcanica 36: 29-49.

Migoń P., Kasprzak M., 2011. Morfologiczny zapis ruchów masowych na progach morfologicznych Gór Stołowych w świetle numerycznego modelu wysokości o dużej rozdzielczości. Przyroda Sudetów 14: 115-124.

Migoń P., Kasprzak M., 2012. Rzeźba północnego progu Gór Stołowych w rejonie Białej Skały. Przyroda Sudetów 15: 155-168.

Migoń P., Latocha A., Parzóch K., Kasprzak M., Owczarek P., Witek M., Pawlik Ł., 2011. Współczesny system morfogenetyczny Gór Stołowych. In: T. Chodak, C. Kabała, J. Kaszubkiewicz, P. Migoń, J. Wojewoda (eds.), Geoekologiczne warunki środowiska przyrodniczego Gór Stołowych, WIND, Wrocław: 1-52.

Migoń P., Pánek T., Malik I., Hradecký J., Owczarek P., Šilhán K., 2010. Complex landslide terrain in the Kamienne Mountains, Middle Sudetes, SW Poland. Geomorphology 124: 200-214. http://dx.doi.org/10.1016/j.geomorph.2010.09.024

Migoń P., Parzóch K., 2008. Spływy gruzowe w polskich Karkonoszach - przyczyny, skutki i zagrożenia. Przegląd Geograficzny 80: 385-401.

Migoń P., Placek A., 2007. Rock control and geomorphology of a rocky sandstone scarp, Middle Sudetes Mountains, SW Poland. Zeitschrift für Geomorphologie. N.F. 51, S1: 41-55.

Migoń P., Placek A., Żyszkowska W., 2009. Steep slopes in the Sudetes and their morphotectonic interpretation. Geological Quarterly 53: 219-232.

Migoń P., Potocki J., 1996. Rozwój morfotektoniczny centralnej części Gór Izerskich. Acta Universitatis Wratislaviensis 1808, Prace Instytutu Geograficznego A8: 69-80.

Napieralski J., Barr I., Kamp U., Kervyn M., 2013. Remote Sensing and GIScience in Geomorphological Mapping. In: J. Shroder (editor in chief), Bishop M.P., Treatise on Geomorphology. Vol. 3. Remote Sensing and GIScience in Geomorphology. Academic Press, San Diego: $187-227$.

Notebaert B., Verstraeten G., Govers G., Poesen J., 2009. Qualitative and quantitative applications of LiDAR imagery in fluvial geomorphology. Earth Surface Processes and Landforms 34: 217-231. http://dx.doi.org/10.1002/esp.1705

Oberc J., 1975. Neotektoniczny rów Rozdroża Izerskiego. Współczesne i neotektoniczne ruchy skorupy ziemskiej w Polsce 1. Wyd. Geologiczne, Warszawa: 157-170.

Olaya V., 2004. Basic morphometric analysis. In: A gentle introduction to SAGA GIS. Edition 1.1 - Rev., December 9: 97-102.

Olaya V., Conrad O., 2009. Geomorphometry in SAGA. In: T. Hengl, H.I. Reuter (eds.), Geomorphometry. Concepts, Software, Applications. Developments in Soil Science 33. Elsevier, Amsterdam: 293308.

http://dx.doi.org/10.1016/S0166-2481(08)00012-3

Ouvrier H., 1933. Beiträge zur Morphologie des Hohen Riesengebirges. Veröffentlichungen der schlesischen Gesellschaft für Erdkunde 17: $1-88$.

Partsch J., 1882. Die Gletscher der Vorzeit in den Karpathen und den Mittelgebirgen Deutschlands. W. Koebner, Breslau: 198 pp.

Pilous V., 1973. Strukturní mury v Krkonoších - I. část. Opera Corcontica 10: $15-69$. 
Placek A., 2011. Rzeźba strukturalna Sudetów w świetle pomiarów wytrzymałości skał i analiz numerycznego modelu wysokości. Rozprawy Naukowe Instytutu Geografii i Rozwoju Regionalnego Uniwersytetu Wrocławskiego 16. 190 pp.

Placek A., Migoń P., 2007. Rock-landform relationships in the Sudetes in the light of rock strength assessment using the Schmidt hammer. In: A.S. Goudie, J. Kalvoda (eds.), Geomorphological Variations. Nakladatelství P3K, Prague: 287-311.

Placek A., Migoń P., Żyszkowska W., 2007. Low-gradient surfaces in the Sudetes - insights from the digital elevation model. Universitatis Ostravensis Acta Facultatis Rerum Naturalium 237, Geographia - Geologia 10: 94-110.

Pulinowa M.Z., 1989. Rzeźba Gór Stołowych. Prace Naukowe Uniwersytetu Śląskiego w Katowicach 1008, Wydawnictwo Uniwersytetu Śląskiego, Katowice: 218 pp.

Sekyra J., 1961. Působení mrazu na půdu: Kryopedologie se zvláštním zřetelem k ČSR. Geotechnica (Prague) 27: 1-164.

Sekyra J., 1964. Kvarterní geologické a geomorfologické problemy krkonošského krystalinika. Opera Corcontica 1: 7-24.

Sørensen R., Zinko U., Seibert J., 2006. On the calculation of the topographic wetness index: evaluation of different methods based on field observations. Hydrology and Earth System Sciences 10: 101-112. http://dx.doi.org/10.5194/hess-10-101-2006

Sroka W., 1997. Ewolucja morfotektoniczna Sudetów w rejonie Kotliny Kłodzkiej w świetle analizy morfometryczno-statystycznej. Acta Universitatis Wratislaviensis 1975, Prace Geologiczno-Mineralogiczne 58: $97 \mathrm{pp}$.

Strzeliński P., Bałazy R., Zawiła-Niedźwiedzki T., 2008.Szkody powodziowe na terenie LKP Sudety Zachodnie. Studia i Materiały Centrum Edukacji Przyrodniczo-Leśnej 10, 2(18): 346-349.

Traczyk A., 1989. Zlodowacenie doliny Łomnicy w Karkonoszach oraz poglądy na ilość zlodowaceń plejstoceńskich w średnich górach Europy. Czasopismo Geograficzne 60: 267-286.

Traczyk A., 1995. Morfologia peryglacjalna Śnieżki i Czarnego Grzbietu w Karkonoszach. Czasopismo Geograficzne 66: 157-173.

Traczyk A., 2007. Pokrywy głazowo-blokowe zachodnich Karkonoszy w rejonie Szrenica-Śnieżne Kotły. Opera Corcontica 44/1: 107-116.

Traczyk A., 2009. Zlodowacenie Śnieżnych Kotłów w Karkonoszach Zachodnich w świetle analizy morfometrycznej oraz GIS. Opera Corcontica 46: 41-56.

Traczyk A., Kasprzak M., 2012. Morfologia masywu Zielonej Kopy w Górach Izerskich w świetle danych LIDAR i analizy geomorfometrycznej. Przyroda Sudetów 15: 169-188.
Traczyk A., Migoń P., 2003. Cold-climate landform patterns in the Sudetes. Effects of lithology, relief and glacial history. Acta Universitatis Carolinae, Geographica 35, Supplement: 185-210.

Traczyk A., Woronko B., 2010. Zlodowacenie doliny Łomnicy w Karkonoszach w zapisie mikromorfologii powierzchni ziarn kwarcowych. Przegląd Geologiczny 58: 1182-1191.

Treml V., Jankovská V., Petr L., 2006. Holocene timberline fluctuations in the mid-mountains of Central Europe. Fennia 184(2): 107-119.

van den Eeckhaut M., Poesen J., Verstraeten G., Vanacker V., Nyssen J., Moeyersons J., van Beek L.P.H., Vandekerckhove L., 2007. Use of LIDAR-derived images for mapping old landslides under forest. Earth Surface Processes and Landforms 32: 754-769. http://dx.doi.org/10.1002/esp.1417

Vítek J., 1979. Pseudokrasové tvary v kvádrových pískovcích severovýchodních Čech. Rozpravy ČSAV, řad MPV 89, 4: 1-57.

Wasklewicz T., Staley D.M., Reavis K., Oguchi T., 2013. Digital Terrain Modeling. In: J. Shroder (editor in chief), M.P. Bishop (ed.), Treatise on Geomorphology. Vol. 3. Remote Sensing and GIScience in Geomorphology. Academic Press, San Diego: 130-161.

Wilson J.P., Bishop M.P., 2013. Geomorphometry. In: J. Shroder (editor in chief), M.P. Bishop (ed.), Treatise on Geomorphology. Vol. 3. Remote Sensing and GIScience in Geomorphology. Academic Press, San Diego: 162-186.

Wilson J.P., Gallant J.C., 2000. Terrain Analysis. Principles and Application. John Wiley and Sons, Chichester: 479 pp.

Wojciechowski T., Borkowski A., Perski Z., Wójcik A., 2012. Dane lotniczego skaningu laserowego w badaniu osuwisk - przykład osuwiska w Zbyszycach (Karpaty Zewnętrzne). Przegląd Geologiczny 60: 95-102.

Wojewoda J., Białek D., Bucha M., Głuszyński A., Gotowała R., Krawczewski J., Schutty B., 2011. Geologia Parku Narodowego Gór Stołowych - wybrane zagadnienia. In: T. Chodak, C. Kabała, J. Kaszubkiewicz, P. Migoń, J. Wojewoda (eds.), Geoekologiczne warunki środowiska przyrodniczego Gór Stołowych. WIND, Wrocław: 53-96.

Wójcik A., Wężyk P., Wojciechowski T., Perski Z., Maczuga S., 2013. Geologiczna i geomorfologiczna interpretacja danych z lotniczego skaningu laserowego (ALS) rejonu Kasprowego Wierchu (Tatry). Przegląd Geologiczny 61: 234-242.

Zeuner F., 1928. Diluvialstratigraphie und Diluvialtektonik im Gebiet der Glatzer Neisse. Universitätsverlag Robert Noske, Borna-Leipzig: 72 pp.

Żurawek R., 1999. Relict rock glaciers in the Central European Mid-Mountains. State-of-the-art. Biuletyn Peryglacjalny 38: 163-192. 